\title{
THE WRITING OF HADITH IN THE ERA OF PROPHET MUHAMMAD A Critique on Harun Nasution's Thought
}

\section{Daud Rasyid*; Aisyah Daud Rasyid**; Asmuliadi Lubis***; Mohd Abd Wahab Fatoni Bin Mohd Balwi***; Bilal Daud Rasyid****}

*State Islamic University (UIN) Syarif Hidayatullah; **STID M.

Natsir; ${ }^{* * *}$ University of Malaya; ${ }^{* * * *}$ International Islamic University Malaysia

email:daud.rasyid@uinjkt.ac.id

\section{Abstract}

The discussion regarding the writing of hadith during the life of the Prophet is a contentious topic within the area of Islamic and hadith studies both in the West and in the Islamic world. Orientalists write their work on badith with a presumption that hadith has never been written during the life of Prophet Muhammad. They contend that hadith text only emerged in the third century of Hijrah, i.e. in the era of al-Bukhari. A few others believe that it started in the era of Malike of the Umayyad. This orientalist' mindset affects some Muslim intellectuals who accept this premise. One of them is Harun Nasution, a well respected great mind who wrote a book entitled Islam Ditinjau Dari Berbagai Aspeknya (Islam Viewed from Various Aspects). However, historical evidence demonstrates that the writing of hadith was carried out at the time when the Prophet was still alive. A number of sheets were discovered, which contain hadith text compilations narrated by the companions of the Prophet, such as the Șabifah of 'Ali bin Abi Talib, Șahifah of Jäbir bin 'Abdillah, and others. Some scholars have misunderstood the message in a saying of the Prophet that probibited the writing of hadith. They have ignored other hadith that negated the previous hadith by which the Prophet allowed the writing 
Daud Rasyid et al.

of hadith in his life time. Even though there are a number companions who did not write hadith in this period, it does not mean hadith were not allowed to be written, but it was due to their own preference not to write the hadith. Perdebatan tentang penulisan hadits masa kehidupan Nabi tetap menjadi tema yang hangat dalam kajian keislaman dan kajian hadits, baik di barat maupun di dunia Islam sendiri. Beberapa orientalis berpendapat bahwa hadits tidak ditulis pada masa Nabi Mubammad. Mereka menyebutkan teks hadits mulai muncul abad ketiga hijriah, misalnya pada era Bukhari. Lainnya percaya bahwa teks hadits dimulai pada masa Malik al Umayyad. Perspektif seperti orientalis ini diterima oleh beberapa intelektual muslim Indonesia, salah satunya Harun Nasution yang menulis bukeu Islam ditinjau dari Berbagai Aspeknya. Bagaimanapun bukti sejarah menunjukkan penulisan hadits sudah dimulai ketika Nabi masib hidup. Sejumlah lembaran yang mengandung kompilasi teks hadits dari beberapa sababat Nabi seperti, Șahifah dari Ali bin Abi Țalib dan Șabifah dari Jäbir bin 'Abdillah. Sejumlah akademisi keliru dalam memahami pesan Nabi yang melarang menuliskan hadits. Mereka mengabaikan hadits yang menegasikan hadits sebelumnya yang membolebkan penulisan hadits selama hidup Nabi. Meskipun ada sejumlah sahabatyang melarangnya, namun ini bukan berarti hadits tidak diijinkan untuk ditulis, tetapi hal ini lebih terkait dengan masingmasing referensi untuk tidak menuliskannya.]

Keywords: Harun Nasution, Hadith Writing, Prophet's era, Orientalist, Sahifah.

\section{A. Introduction}

Hadith is the second source of Islamic law for Muslims. Without hadith, Islamic Law will be difficult to implement, either in issues related to individuals or to society and nation. Generally, the position of the hadiths is to provide further explanation and details of the Qur'an. Due to the important position and role of hadith in elaborating the messages of the Qur'an, many parties outside Islam have tried to break the strength of the hadith and search for its weaknesses from many different angles to the point of ignoring scientific research principles. But because Islamic Studies has become an open discipline of knowledge for everyone, believer or non-believer, so there is no reason to restrict people to convey 
their thoughts and criticisms on Islamic Studies. However, if a claim is directed to Islamic Studies on aspects that do not have a strong basis (bujjab), whether naqly (written) or 'aqly (thoughts), the claim will fall by itself in front of scientific studies. The duty of Muslim intellectuals is to expose the weaknesses of the analysis and the claims based on scientific reasoning as well, whether Naqly or 'Aqly.

One of the topics that are often used as the target spot by orientalists and their supporters is the writing of hadith in the era of the Prophet. Why does this topic become an important topic in the study of orientalists? The answers are as follows: If it is proven that hadith has never been written when the Prophet was still alive, it opens a possibility that the hadith that are available now are not the product of early Islam, but heritages that were written later. Western Orientalists do not believe in heritage in the form of memorisation, because their culture in science do not recognise memorisation culture. As if they wanted to say that the validity of something that is not written cannot be justified. They want to enforce this culture to all world civilisation heritages to follow the standard of their validity. However, it is recognized that what happened at the time of the Prophet was the writing of hadith, ${ }^{1}$ as the Prophet had scribes to write down various things in his day. ${ }^{2}$ As for bookkeeping, which is commonly known as "codification", it happened in later times such as the time of the Imams who collected Hadith.

The followings are some arguments that have underpinned the need to further explore the debate on the writing of hadith, namely: The issue of hadith writing in the era of the Prophet up until now is still a topic of debate in among researchers, especially orientalists who are keen with the study of hadith. Even though there are many studies by Muslim scholars and academics that are published in the West or in the Muslim world that respond to the orientalists' contention in the area of hadith writing in the early time of Islam, Western researchers who come later still reiterated assertions of their predecessors such as Goldzieher, hence give an impression that western researchers intentionally want to

1 Muhammad Ied Mahmud, "Kitābat al-Hadīth fī 'Aṣr al-Ṣahābah", Majallah al-Jami'ah li al-Dirasat al-Islamiyah (Journal of Islamic Studies), vol. 28, no. 1 (2020), p. 78.

2 Mohamad Ali Huseen and Basim Kanaan Saleh, 'al-Kuttāb fī al-'Ahd alNabawy (In the book During Prophet Muhammad Era)', Journal of Research Diyala Humanity, no. 47 (2010), p. 564. 
make this topic remains permanently and do not wish to end the debate although there are very clear scientific evidences delivered by Muslim researchers in the West and in the East. Unfortunately, the orientalist followers are not only in the West, but they can also be found amongst Muslim researchers. Prof. Harun Nasution is a very well-known figure in the Islamic academic community in Indonesia, he was the Rector of the State Institute for Islamic Studies or IAIN. He is known as a scholar from the early generation that brought orientalist thoughts to Indonesia once he came back from Canada. The book that brought this theory is his book entitled Islam Ditinjan Dari Berbagai Aspeknya (Islam viewed from various aspects) that becomes the handbook for students of IAIN throughout Indonesia, and even in the University of Indonesia for the course of "Pendidikan Agama" (Religion Education). Thus, it can be imagined the impact of this book in affecting the mind of college and university students in Indonesia as it contains serious errors that goes against historical facts.

This article seeks to answer the questions of whether the hadith were written and memorised during the Prophet's time. In order to answer the question, classical and contemporary scholarly works are probed and analysed. The analysis proved the assertion that the argument that no hadith were written nor memorised in the time of the Prophet was inaccurate and founded upon weak evidence and argument.

\section{B. Claim that Hadith were Not Written in the Prophet's Time}

Harun Nasution claims that Sunnah (traditions, narrations) are not written nor memorised in the time of the Prophet but in the second century of Hijri calendar. ${ }^{3}$ We posit that this opinion is much more misleading than the orientalists' view. Even an orientalist with the calibre of Goldzieher who is known for his hostility toward Islam-for example, did not go to such an extent in his position. In relation to the matter, Goldzieher states,

The writing down of the hadith was a very ancient method of preserving it, and that reluctance to preserve it in written form is merely the result of later considerations. The oldest parts of the hadith material are

${ }^{3}$ Harun Nasution, Islam Ditinjau Dari Berbagai Aspeknya, vol. 1 (Jakarta: UI press, 1985), pp. 28-30. 
presumably those of which it is said that they were already preserved in writing during the first decades. There is nothing against the assumption that the Companions and disciples wished to keep the Prophet's sayings and rulings from being forgotten by reducing them to writing. ${ }^{4}$

Goldzieher did not object to evidences in favour of the occurrence of hadith writing during the time of the Prophet. It is quite astonishing that a Muslim intellectual could deny something that the orientalists themselves did not.

Given the importance of this issue, we are aware of the necessity to analyse the writing of the hadith in the time of the Prophet. It is also necessary to mention that this rebuttal has been expressed by many Islamic contemporary scholars. These Muslim scholars, for example, include Mușțafa As-Sibā iii ${ }^{5}$, Muḥammad 'Abū Shahbah', Muhammad Muștafā Al Áżami ${ }^{7}$, and Rif 'at Fawzi. ${ }^{8}$ Their research on this topic shows accurate and scientific rebuttals with regard to claims denying the writing of the hadith in the early time of Islam. It is necessary to emphasise that in studying this issue, the orientalists are faced with various nas (text) which, at a glance, seem to be contradictory. On one hand, there are some texts-whether it is hadith or 'athar-that prohibit the writing of Sunnah. On the other hand, there are texts that allow the writing of hadith, or even commanded its writing.

Due to the limited vision and knowledge on this issue, orientalists cannot present their argument correctly. They cannot compare and contrast these hadith texts, neither can they make a judgment to make a compromise nor choose the strongest evidence. The problem is that this kind of scientific work requires specialization, thorough research, comprehensive insights, and clear understanding. All of these

${ }^{4}$ Ignaz Goldziher, Muslim Studies, vol. 2 (Albany: State University of New York Press., 1971), p. 22.

5 Muștafá Sibāīì, As-Sunnah wa Makēnatubā fì at-Tashrī al-Islāmiy (Cairo: al-Dār al-Qawmīyah lil-Ṭibā'ah wa-al-Nahsr, 1966).

${ }^{6}$ Muḥammad 'Abū Shahbah, Difä́ 'an as-Sunnah (Cairo: Mağma' al-buhūūt al-islāmiyyah, 1985).

7 Muhammad Musțafā al-Aẓamī, Dirāsāt fì Hadìth al-Nabawì wa Tärìkh Tadwinnih, vol. 1 (Beirut: Manshūrāt al-Maktab al-Islāmī, 1992).

8 Rife at Fawzi, Tautsiq al-Sunnah fi al-Qarni Assani al-Hijri. (Cairo: Maktabah al-Khanji, 1981). 
qualifications may only be achieved by people who are guided by Allāh, in addition to having deep Islamic knowledge and free from prejudices. When faced with this situation, orientalists encountered difficulties and are stricken by confusion. They then choose an easiest shortcut to draw conclusion that the Prophet prohibited the writing of hadith.

Without a deep study, there are two possibilities that encourage them to spread this opinion, namely: First, there are indications and signs that lead to this opinion, such as narrations that clearly explain the prohibition of writing the hadith. Second, the prohibition of writing the hadith in the Prophet's time is the most appropriate opinion with orientalists' interest and target. As known, some of the orientalists-not to say the majority-are against Islam since the beginning, due to their academic background and beliefs. As a result, they lost their objectivity and fairness. Evidences demonstrate that the writing of the hadith at the time of the Prophet is an undeniable fact. ${ }^{9}$ There are numerous narrations from the Prophet, the companions, and the tabi in (companions of companions), with the bases that are qat iy or doubtless. It is true, there are narrations that prohibit the writing of the hadith. But all of these have been clarified by Al-Khatīb Al-Baghdādy. He included all of these narrations in his book Taquid Al- $\mathrm{Tlm}$, in addition to some other narrations that allow or even command the writing of the hadiths. ${ }^{10}$ The scholars compare these various hadith texts that seem contradictory. ${ }^{11}$ They concluded that there is only one hadith that is sabih (authentic) that prohibits the writing of hadith, ${ }^{12}$ i.e. narrated by Hammām from Zayd Ibn Aslam from 'Ațā' Ibn Yasār, from 'Abū Sa îd al-Khudry, in which the Prophet said: "Do not write from me, whoever writes from me beside the Qur' an let him erase it, and convey things that come from me, and no problems, and those whoever lie by me - Hammām says: I

${ }^{9}$ Fathi Daday Baba, "Kitābat al-Hadīth fī Zaman al-Naby bayna al-Nafyi wa al-Ithbāt", Al-Haqiqah Journal, vol. 15, no. 37 (2016), p. 151.

10 Ahmad Ma'bad Abd al-Karim, Kitābat al-Hadìth fì 'ahd al-Naby wa Sahābatibi (Medina: Majma’ al-Malik Fahad Li Thiba’at al-Mushaf, 2020), pp. 1-4, https:/ /www. islamspirit.com/islamspirit_ilmolma_002_00023.php, accessed 27 Nov 2020.

${ }^{11}$ Hassan Rukabah, "Tațawwur Kitābah al-Hadīth al-Nabawī al-Sharīf ilā Aṣr al-Tadwīn”, Al-Mi'yar Journal, vol. 16, no. 32 (2020), p. 138.

12 'Abd al-Raḥmān Ibn Yahyyā al-Mu'allamī, Al-Anwār al-Kāshifah Limā Warada fi Kitāb Aḍ̂' 'ala al-Sunnah min al-Zalal wa al-Tadlil wa al-Mujärafah (Cairo: al-Mațba 'at al-Salafiyyah, 1953), p. 35; al-' A 'zamì, Diräsät fì Hadìth al-Nabawì wa Tärikeh Tadwinnih, 1: 80. 
think- he says: intentionally, let him prepare his seat from the hell fire."13 This hadith was narrated by Muslim in his Șahịh book. However, scholars have different opinions about this hadith, is it mawquif (the chain only reaches the companion) or marf $\bar{u}^{\prime}$ (the chain reaches the Prophet). Some of the scholars tend to categorise this hadith as mawqüf up to 'Abū Sa id al-Khudry, and does not reach the Prophet. Ibnu Hajar says, "Some scholars have an opinion that the hadith of 'Abu $\mathrm{Sa}$ ìd is flawed. The correct opinion is that the narration is mawqü on 'Abū Sa ìd. This is disclosed by al-Bukhāry and others." ${ }^{14}$ The above explanation indicate that the correct position is that the narration was a saying of 'Abū Sa îd al-Khudry, then some of the narrators made the mistake in indicating that it is a saying of the Prophet. ${ }^{15}$

Amongst the arguments that support this opinion -as mentioned by 'Abd al-Rahmān al-Mu 'allamī- are narrations which are mawqüf from Abū Saìd that is similar to the hadith above, as explained by Ibn 'Abd al-Barr in Kitäb al-'Ilm from some paths that are not mentioned from the Prophet. ${ }^{16}$ In this light, we tend to agree with Muhammad 'Ajjāj al-Khatỉb, that hadith of 'Abū Saìd al-Khudry is marfü from the Prophet because it is narrated by Muslim in his S,ahin. ${ }^{17}$ With all of his credibility in hadith science, it is strange if this is not recognised by Muslim. Moreover, alBukhāry who lived in the same era of Muslim narrated various hadiths that allow the writing of hadiths in his book. If only the hadith is not marfü, surely Muslim will not mention it as a marfü hadith. None of other hadiths about writing prohibition is free from flaw hence they cannot be used as arguments. ${ }^{18}$

${ }^{13}$ Muslim ibn al-Hajjāj al-Nīsābūrī and Muḥammad Fu' ad 'Abdul Bāqī, Saḥīh Muslim (Cairo: Maktabat 'Îsā al-Halabī, 1954), chap. al-Tashāddud fī al-Hadīith no. 3004.

${ }^{14}$ Aḥmad ibn 'Alī Ibn Hajar al-Asqalānī, Fath al-Bārì, vol. 1, ed. by Muhib al-dīn al-Khațīb (Cairo: Maktabat al-Salafiyyah, 1986), p. 251; al-Mu allamī, Al-Anwār al-Käshifah Limā Warada fì Kitāb Aḍwa' 'ala al-Sunnah min al-Zalal wa al-Tadlil wa al-Mujārafah, p. 43.

15 al-Mu allamī, Al-Anwār al-Kāshifah Limà Warada fì Kitāb Adwà 'ala al-Sunnah min al-Zalal wa al-Tadilil wa al-Mujärafah, p. 35.

${ }^{16}$ Ibid.

17 Muhammad 'Ajjāj, al-Sunnah Qabla al-Tadwin (Cairo: Maktabat Wahbah, 1963), p. 306.

18 There are some narrations from the Prophet about the prohibition of the writing of the Hadīth through three companions: Abū Saīd al-Khudrī, Abū Hurayrah, and Zaid Ibn Thabit.. Sheikh 'Abd al-Rahmān al-Mu' allamī in his book Al-Anwār 


\section{Claims that Umar Withdrew His Opinion about Codification}

Nasution wrote in his book that Umar cancelled his intention on writing the hadith, as cited: "Umar ibn al-Khattāab has ever had an intention to collect the hadiths and to record it. He then withdrew his intention because of the worry of mixing the Qur'an with hadith." ${ }^{19}$ Perhaps this is the reason for Nasution - without mentioning the source, asserted that there was no writing of hadiths at the time of the Prophet. This narration originated from 'Urwah Ibn Zubayr who mentioned that Umar ibn al-Khattāb intended to facilitate the writing of hadiths. Umar then asked for the opinions of the companions of the Prophet and they gave a sign of agreement. Umar then perform istikharah prayer to Allāh for a month, until he then firmly says at a time, "Truly, in the past I wanted to write the sunnah. I have ever mentioned a tribe before you who wrote various books until they got busy and left the Book of Allāh. By Allāh, I do not want to mix the Book of Allāh with anything, forever." ${ }^{20}$

This narration is rebutted from many aspects: First, the narration of Urwah ibn Zubayr from 'Umar ibn Khațāāb, the sanad (chain) is broken. By itself, this narration is weak and cannot be used as a buijah (guidance). ${ }^{21}$

al-Käshifah and al-' A 'zuamī in his book Dirāsāt fì Hadìth al-Nabawì each one has investigated the Hadith and explained the flaws embedded inside. As for Hadīth 'Abū Saīd, in one of the narrators' name there is 'Abd al-Rahmān Ibn Zayd Ibn Aslam, this person is agreed his weakness. See: Muhammad ibn Aḥmad al-Dhahabī, Mì̄àn al-I'tidāl fì Naqd al-Rijäl, vol. 2, ed. by Ali Muhammad al-Bajāwī (Cairo: Maktabat 'İsā al-Halabī, 1962), p. 564. As for another narration it is in Șahịh Muslim, hence that Hadīth is Sahīḥ (authentic), as we mentioned before. As for the Hadith of 'Abū Hurayrah, one of the narrators is 'Abd al-Rahmān Ibn Zayd as well, which is judged as weak. Whereas in another narration which is contained by al-Khațīb al-Baghdādy in the book of Taqvìd al- ' $\mathrm{Im}$, p. 34, which is narrated by 'Alī ibn Sahal from his father from 'Abd al-Rahmān ibn Zayd. Regarding this narration, al-Dhahabī commented that this narration is "munkar" (evil). See Ibid., 2: 566. As for the one narrated by Zayd ibn Thābit, also weak, because there is a narrator called Kathīr ibn Zayd, he is not strong (ghayru qowr). Also al-Muțalib ibn 'Abd Allāh does not hear the Hadīth from Zayd. See, A ḥmad Ibn Ali Ibn Hajar al-Asqalāniī, Tahdhīb al-Tahdhìb, vol. 10 (Hyderabad: Dār al-Ma'ārif al-Niẓāmiyyah, 1907), p. 179.

19 Nasution, Islam Ditinjau Dari Berbagai Aspeknya, 1: 28-31.

20 Aḥmad ibn 'Alī al-Khațīb al-Baghdādī, Taquìd al- 'Ilm, ed. by Yusuf al- 'Ish (Damascus: Dār Ihyā al-Sunnah al-Nabawiyyah, 1974), p. 49.

${ }^{21}$ Aḥmad Ibn Ali Ibn Hajar al-Asqalāniī, Tahdhïb al-Tahdhīb, vol. 7 (Hyderabad: Dār al-Ma ārif al-Nizāamiyyah, 1907), p. 183. Muṣ ab al-Zubayr says: 'Urwah was born in the sixth year of 'Uthmān caliphate. 
Second, even though this narration is considered sahįh (authentic), in it there is a sign of agreement (ijmát) of the companions to carry out the writing, when 'Uthmān asked their opinions. In other words, they did not know the prohibition by the Prophet on the writing of the hadith. If they knew that the prohibition exists, certainly they rejected 'Umar's intention to write the hadith. This did not happen. On the contrary, they agreed with 'Umar's proposal. Therefore, the cancellation of 'Umar's plan on writing hadith was not based on a hadith of the Prophet nor consultative with companions, but solely based on his own judgment (ijtihäd). The consideration, as espoused by Al-A'żamy, 'Umar's intention is to give priority to The Book of Allāh (Kitäbullāh) because the script and its meaning have to be memorised. This is different from hadiths, of which are sufficient to memorise the meaning, and that is easier. ${ }^{22}$ From a different perspective, even though this narration is authentic (sabiji), the concern occurred during the era of 'Uthmān and then disappear. Urwah himself said, "First we reckoned not to write any book except the Qur'an, hence I erased all of my books. By Allāh, I admire if only my books were with me and Kitäbulläh (The Book of God) was continued to be written until finish." ${ }^{23}$ Meaning, the process of writing the Qur' an has completed, and Sunnah (traditions) acts as an explanatory of the Qur'an. Therefore, the concern that people will be busy with hadith that make them leave the Qur'an does not exist anymore. ${ }^{24}$

\section{Scripts that Allow the Writing of Hadith}

The number of narrations that allow the writing of the hadith is huge. This is explained by al-Khațīb al-Baghdādy in his book Taqyìd Al$\mathrm{Ilm}$. Included in it is a narration from companions and companions of companions (tabi inn). Even al-Bukhāry makes a specific chapter "Hadith Writing" in his Șahịh Book which includes several hadiths that clearly allow it. This is explained in more detailed as follow.

First, al-Bukhāry starts this chapter with a story of Șahifah (a sheet) that was on the hand of Ali r.a, a narration of 'Abū Juhayfah. He says,

22 al-' A 'ẓamī, Dirāsāt fì Hadìth al-Nabawì wa Tärīkh Tadwinìh, 1: 133.

23 See the biography of 'Urwah in al-Asqalāniī, Tahdhìb al-Tahdhìb, 7: 183.

${ }^{24}$ al-Mu allamī, Al-Anwār al-Käshifah Limā Warada fì Kitāb Adwà' 'ala al-Sunnah min al-Zalal wa al-Tadilil wa al-Mujärafah, p. 38. 
I said to Ali, "Do you have a book?" Ali replied, "There is none except The Book of Allāh (the Qur' an), understanding that is given to a Muslim and this Sahifah." He says, I asked, "What is in this Șabifah?" Ali replied, "Laws of 'aql (fine, ransom), to release prisoners, and a Muslim is not to be killed for killing a käfir." 25 Second, al-Bukhāry includes a narration from 'Abū Hurayra about the sermon of the Prophet at Fathu Makkah (the liberation of the city of Makkah) and a request from a companion to write that sermon. Then comes a man from Yemen and says, "Write for me o Prophet of God!" the Prophet of Allāh says, "Writes for Abū Fulān." Also, a man from Quraysh comes and says, "Except the plants of al-Idhkhir, o Prophet of Allahh because we use them for household and grave." 'Abū 'Abdullāh was asked, what was written for him? He replied, "This sermon was written for him."26 Third, 'Abū Hurayrah's statement, "There is no Prophet's companion that has more Hadith than me except 'Abdullāh bin 'Amr, because he writes and I do not write." 27 Fourth, a narration of Ibnu 'Abbās about a story of the illness of the Prophet and he says, "Bring me a book. I will write a book so that you will not be lost thereafter." ${ }^{28}$ This hadith shows his eagerness to write a book for his people so that they are avoided from disunity. Ibnu Hajar says, "He is not eager except in the truth." 29

There are many other narrations with similar sense, whether hadiths or 'athär from the companions or tabinn. Even we can say, whenever a narration that prohibits the writing of the knowledge exists, there is another narration that ascertain and allow it. Therefore, writing the sunnah among the companions and the next generations could no longer be denied. ${ }^{30}$

\section{E. Critiques and Answers}

Perhaps one thinks, although there are many narrations that allow the writing of the hadith, including among the companions and tabi ${ }^{\mathrm{i}} \mathrm{n}$, the authentic narrations that prohibit the writing cannot be ignored.

${ }^{25}$ al-Asqalānī, Fath al-Bārì, 1: 246 no. 111.

26 Ibid, Hadith no.: 112

${ }^{27}$ Ibid, Hadīth no.: 113

28 Ibid, Hadīth no.: 114

29 al-Asqalānī, Fath al-Bārì, 1: 253.

30 al-' A 'ẓamī, Dirāsāt fì Hadìth al-Nabawi wa Tärìkh Tadwinih, 1: 251. 
How do we deal with this contradiction correctly? The answer is that, parts of these narrations are authentic and cannot be neglected. The most appropriate approach is to compromise. ${ }^{31}$ Ibn Hajar al- 'Asqalāni offers compromise concept in dealing with contradictive narrations. ${ }^{32} \mathrm{He}$ summarises as follows:

- This prohibition was valid specifically during the Qur'an revelation. The Prophet prohibits the writing of the hadith only on that period, so that the Qur' an is not mixed with others. After that period, this prohibition is not valid any longer. Ibnu Hajar says, "That this prohibition was addressed specifically when the Qur' an was revealed, because of the worry of mixing with others. Later, the writing was allowed." This interpretation was also mentioned by Suyūti in the book Tadrīb ar-Räny. ${ }^{33}$

- This prohibition means it is not allowed to write the Qur' an and other information on one sheet. If it was written separately, it would have been allowed. The reason is the same as of point 1 above. Similar interpretation was also revealed by al-Suyūṭi in Tadrïb ar-Räny and al'Irāqy in Fatḥ al-Mughith. ${ }^{34}$ This view is the one chosen by Muhammad al-'A'zamī, for two reasons ${ }^{35}$ : First, the Prophet dictates and the companions write the hadiths of the Prophet that reach mutawatir degree. Second, the Prophet allows the writing of the hadith.

- The narrations that prohibit the writing are invalid, and therefore are annulled by the narrations that allow it. Ibnu Hajar says, "The prohibition comes earlier, and the writing permission comes later, when there is no concern of mixing in the writing. This opinion is closer to the truth and no contradiction to each other. ${ }^{36} \mathrm{Al}$ - Irāqy agreed with this opinion. ${ }^{37}$

31 Mahmud Idan Ahmad, "Tadwīn al-Hadīth 'ala 'ahd al-Naby wa Ṣahābatihi”, Journal of Tikrit University for the Humanities, vol. 13, no. 2 (2006), p. 14.

32 al-Asqalānī, Fath al-Bārì, 1: 251.

33 Jalāl al-dīn 'Abd al-Raḥmān al-Suyūṭī, Tadrīb al-Rāwī fì Sharḅ Taqrīb al-Nawawi, vol. 2, ed. by 'Abd al-Wahhāb 'Abd al-Lațîf (Cairo: Dār al-Kutub al-Hadīth, 1965), p. 67.

${ }^{34}$ Muḥammad ibn 'Abd ar-Rahmān al-Sakhāwī, Fatḥ al-Mughith Sharh Alfivyat al-Hadith, vol. 3 (Saudi Arabia: Wizarat al-Shu'un al-Islamiyah wa al-Awqaf wa al-Da'wah wa al-Irshad, 2003), p. 18.

35 See al-'A 'ẓamī, Dirāsāt fì Hadìth al-Nabawì wa Tärikh Tadwinìih, 1: 79.

36 al-Asqalānī, Fath al-Bārì, 1: 251.

37 al-Sakhāwī, Fatḥ al-Mughith Sharḥ Alfiyyat al-Hadìth, 3: 18. 
Daud Rasyid et al.

- Writing permission was given to those people who were worried they would forget, and prohibition was given to people with strong recitation and memory. The intention of this prohibition is so that they did not ignore their strong recitation ability and depended on writing. ${ }^{38}$

There is another form of compromise that was mentioned by scholars: ${ }^{39}$

- The prohibition is addressed to specific people, those who are feared to mix hadiths and the Qur' an (accidently). Permission is addressed to the others. This matter and the one before were expressed by alNawawi and Ibnu As-Ṣalāh. ${ }^{40}$

- Special permission is addressed to those with good reading skill, and prohibition is addressed to those with no good reading skill due to the fear of making mistakes. This opinion is cited from Ibnu Qutaybah. ${ }^{41}$

We posit that the strongest reason for the prohibition of hadith writing in this era is the fear of confiscation of the companions' attention so that they might forget the Qur'an. On top of that is the fear of mixing verses of the Qur'an and hadiths. With this approach, narrations that

38 al-Asqalānī, Fath al-Bārì. through compromise method that was offered by Ibn al-Hajar, we can understand his saying: "the Prophet's Hadith have not been codified in the era of companions and senior tabi in, in an encyclopaedia, and have not been arranged, due to two factors: (1) Because they -the companions- in the beginning were prohibited by the Prophet to do that, as we read in a Hadith narrated by Muslim, because the worry of mixing the Hadith with the verses of the Qur'an, (2) Due to memory factor and their ability to memorise the Hadith, as well as most of them are illiterate." What Ibn Hajar means with his statement above is, the Prophet's Hadith have not been recorded (codified) in a collection (encyclopaedia) as in the era after that. Does not mean 'Ibn Hajar denies the occurrence of the writing of the Hadith in the time of the Prophet as understood by Prof. Muhammad al-' A 'zamī, because this kind of matter is impossible not to be known by Ibn al-Hajar, let alone if we understand the lettering of his saying in the compromise conscript that he offered in his book Fath al-Bär

39 Ismail Abdullah, "Early Blogging for the Year is an Authentic Study and Curriculum", Ma'alim Al-Quran Wa Al-Sunnah, vol. 2, no. 2 (2006), p. 106, http:/ /ddms. usim.edu.my:80/jspui/handle/123456789/15703, accessed 27 Nov 2020.

${ }^{40}$ Muhyi al-dīn ibn Sharaf al-Nawawī, al-Taqrīb, vol. 1 (Cairo: Dār al-Kutub al-Hadīth, 1965), p. 67; 'Uthmān ibn 'Abd al-Rahmān al-Shaharzūrī Ibn al-Ṣalāḥ, alMuqaddimah fì 'Ulüm al-Hadìth, ed. by Nūruddin 'Itr (Damascus: Dār al-Fikr, 1985), p. 182.

41 'Abd Allāh ibn Muslim al-Dīnawarī Ibn Qutaybah, Ta' wil Mukhtalaf al-Hadìth, ed. by 'Abd al-Qadīr 'Ațā (Cairo: Dār al-Kutub al-Islāmiyyah, 1981), p. 251. 
prohibit the writing of hadith can be understood. If this reason is not there anymore, the prohibition automatically is not valid anymore, and vice versa. An authentic narration says that the Prophet allowed 'Abdullāh ibn 'Amr ibn al- 'Aṣ to write hadith because he was diligent and careful in making notes. He was actively involved in the Qur' an collection and he had been tested in this task. He said: "I collected the Qur' an and I read it in one night until I finished reading it." ${ }^{42}$

However, some take a different position. Some of the companions rejected the writing of hadiths so as not to mix them with verses of the Qur'an, therefore not to compete with the words of Allāh. This happened before the Qur'an was collected in a complete scripture. If this is true, this position should change when the reason of the prohibition has not been presented. This is what can be concluded from the position of 'Abū Sa îd (74 AH) when he says: "We do not write except the Qur' an and tashabbud." This conclusion is based on a reality that they wrote other than the Qur' an and hadiths. ${ }^{43}$ If this fear does not exist anymore, and has no reason, this prohibition is invalid. Hence, it can be concluded that the writing of hadith is allowed.

\section{F. Evidence of Hadith Writing in the lifetime of the Prophet}

After explaining the permission from the Prophet for writing hadith in his era, here evidenceswill be shown to support the writing of hadiths. The evidence is the rebuttal against Nasution's claim, that sunnah has not been written and memorised in the era of the Prophet. It is important to remember that codification was officially carried out in the early second century of Hijri calendar, i.e. in the era of Caliph Umar bin 'Abdul'Aziz. The background of this effort was the danger of losing and fabrications of hadiths by irresponsible parties. Individually, hadiths codification has been done in the era of the Prophet, companions, and tabi $i n$. This indicates that it was not neglected or prohibited as argued by Nasution and his friends, who believed that fabrications of hadiths (through writing) occured.

${ }^{42}$ Aḥmad ibn 'Abdillāh al-Aṣbahānī, Hilyat al-Awliy à', vol. 1 (Cairo: Maṭba at al-Sa'ādah, 1974), p. 285.

${ }^{43}$ Yusuf al-'Ish, "Introduction", in Taquìd al- 'Ilm (Damascus: Dār Ihyā al-Sunnah al-Nabawiyyah, 1974), p. 19. 
According to Nasution, it is very difficult to distinguish between șahị ha hadiths and the fabricated ones. This assumption is clearly incorrect. Because, the memorisation and the writing of the hadith in sheets were carried out simultaneously. There are a lot of narrations in hadith books that refer to Sabifah of the companions. ${ }^{44}$ Ibnu 'Abdil Barr narrated with his sanad (chain) from 'Abū Jafar Muhammad ibn 'Ali, he says, "in the scabbard (sword cover) of the Prophet of God it was found a note read "It is cursed, ones who steal land boundary, ones who make guardian on something that he has no right, and ones who deny the grace from someone who gives it." " Nāfi' narrated from 'Abdullāh ibn 'Umar that he has ever found a note inside his father's scabbard, containing descriptions about zakat of animal. ${ }^{46}$ Among the famous sheets in the companions' era is belong to Amirul Mukminin'Ali bin 'Abi Țālib, that he hung on his sword. This sheet contains hadiths about diyät (fines), zakat, dignity of Medina city, and a law that a Muslim is not to be killed for killing a kāfir (disbeliever), and other substances. ${ }^{47}$

Even, 'Abū Hurayrah (59 AH.) who is famous for his hadith memorisation also kept hadiths of the Prophet. Fudhayl ibn Hasan ibn 'Amr ibn 'Umayyah narrated from his father who said, I told 'Abū Hurayrah about a hadith and he denied it. I said, "I heard it from you." 'Abū Hurayrah said, "If you heard it from me I must have it written." He then took me to his house, he showed me books containing many Hadith of the Prophet and he found that Hadith. 'Abū Hurayrah then said, "As I said, if I have ever told you, that hadith is recorded in mine." 48 Another sheet is Sahifah Sädiqah written by Abdulläh ibn 'Amr (7-65 AH) ${ }^{49}$ As known, the Prophet allowed him to write hadith because he

44 'Ajjāj, al-Sunnah Qabla al-Tadwin, p. 343.

${ }^{45}$ Yūsuf ibn 'Abd al-Barr, Jāmì Bayān al-'Ilm wa Fadlih, vol. 1, ed. by 'Abd al-Raḥmān Muḥammad 'Uthmān (Medina al-Munawwarah: al-Maktabat al-Salafiyyah, 1968), p. 86.

${ }^{46}$ Aḥmad ibn 'Alī al-Khațīb al-Baghdādī, al-Kifāyah fì ' Ilm al-Rìwāyah (Beirut: Dār al-Kutub al-'Ilmiyyah, 1974), p. 354; Ṭahhir ibn Șāliḥ ibn Aḥmad al-Jazarī, Tawjīh an-Naz̧ar ilā Ushūl al-Athar (Aleppo: Maktab al-Mațbū'àt al-Islāmīyah, 2009), p. 348.

47 See Rif'at Fawzī, "Introduction", in Sabifat Hammām ibn Munabbih (Cairo: Maktabah al-Khanjī, 1985), p. 4.

48 See al-Barr, Jämī Bayān al-'Ilm wa Fadlìh, 1: 89.

49 Khaulah Hamdun al-Ṣawwaf, "Abdullāh Ibn 'Amr Ibn al-'Ash, Al-Ṣahāōī alMuhaddith”, Journal of Tikerit University for the Humanities, vol. 14, no. 1 (2007), pp. 71-92. 
was known as a diligent and careful person in writing notes. Therefore, it makes sense if he wrote many hadiths of the Prophet.

This sheet belongs to 'Abdullāh ibn 'Amr which contained 1000 hadiths as mentioned by 'Ibnul Athīr. ${ }^{50}$ Mujāhid ibn Jabar (21-104 AH) has seen directly on the hand of 'Abdullāh ibn' Amr, and he met him to obtain them. So, 'Abdullāh said, "Be quiet o son of Makhzūm Tribe." Mujāhid said, "I am not writing anything." He said: This is al-Sādiqah that contains Hadith that I heard directly from the Prophet, without any intermediary at all..$^{51}$

This sheet scientifically has an important value. This is a historical document ${ }^{52}$ that proves the writing of Hadith with the permission of the Prophet. In addition, there are Șahifah which belong to Jābir ibn 'Abdillāh al-Anșāry (16-78 AH) ${ }^{53}$ and Sabifah as-Sahīhah that belongs to Hammām ibn Munabbih (4-131 AH). These sheets have historical value and at the same time reject the assertion of those who challenge Hadith codification before second century Hijri calendar because, Hammām - one of scholars from tabi ìn-met 'Abū Hurayrah. No doubt, he wrote directly from 'Abū Hurayrah in his life, because 'Abū Hurayrah died in 59 AH. This means, recording was done before this year, or mid of first century. ${ }^{54}$

These sheets manage to reach us in one piece, exactly like the narrations and notes of Hammām from 'Abū Hurayrah. These sheets, firstly found and tahqiq (studied/investigated/edited) by Muhammad Hamīdullāh. Then, a second tahqiq was done by Rifat Fawzy by adding some important information. These sheets contain 138 Hadith, exactly as explained by Ibnu Hajar, that Hammām heard around 140 Hadith from 'Abū Hurayrah with one sanad..$^{55}$ There are still many other narrations that explain that the companions codified the Hadith before second century

50 'Alī ibn Muhammad al-Jazarī, Usud al-Ghābah fì Ma' rifah al-Ṣahāāah, vol. 3, ed. by Muḥammad Ibrāhīm al-Bannā (Cairo: Ṭab'at al-Sha'b, 1970), p. 349.

51 Al-Hasan ibn 'Abd al-Raḥmān al-Rāmahurmūzī, al-Muhaddith al-Fāṣil Bayna al-Rāw wa-al-Wā' $\bar{l}$, ed. by M. 'Ajjāj al-Khatīb (Damascus: Dār al-Fikr, 1971), p. 369; al-Baghdādī, Taqyìd al- 'Tlm, p. 84.

52 'Ajjāj, al-Sunnah Qabla al-Tadwin, p. 350.

53 Aḥmad ibn 'Alī al-Khaṭịb al-Baghdādī, al-Kifäyah fì 'Tlm al-Rìwāyah, p. 354.

54 'Ajjāj, al-Sunnah Qabla al-Tadwin, p. 357.

55 Aḥmad Ibn Ali Ibn Hajar al-Asqalāniī, Tahdhïb al-Tahdhïb, vol. 11 (Hyderabad: Dār al-Ma ārif al-Nizāmiyyah, 1907), p. 67. 
of Hijri calendar. It is proven that 'Abdullāh ibn 'Amr codified Hadith in the time of the Prophet in Sabifah al-Sädiqah. Similarly, Sabifab Hammām ibn Munabbih which is an evidence in the half first century of Hijri calendar. This demonstrates that the scholars carried out codification before 'Umar ibn 'Abdul 'Azīz commanded it. Based on the evidences discussed here, it is clear that the writing of Hadith has started since the beginning of the Prophet's era.

\section{G. The Number of Hadith Written by the First Generation}

In this section, the number of Hadith written in the era of the Prophet will be explained. Is it correct that the number is small? As doubted by some, or the number is fair enough in comparison to the ones codified by az-Zuhry in the second century of Hijri.

- To have a good picture about narrations from the companions who directly wrote the Hadith of the Prophet in the first generation, narrations from the companions below can be used as reference. In this case, their narrations are stronger and cannot be doubted. Some of the narrations are:' Abdullāh ibn 'Amr says, "I used to write everything I heard from the Prophet because I wanted to memorise them. But, Quraysh tribe forbid me and say, "Do you write everything that you hear from the Prophet? Whereas he is a human who talks in anger and happiness. So, I stopped writing until I complained of this matter to the Prophet. He then said, "Write, for the sake of whom myself is in His hand, nothing comes out from me except the truth." ${ }^{56}$ This narration explains that 'Abdullāh ibn 'Amr has ever written Hadith that he heard directly from the Prophet. The following narration also indicates the Prophet's permission to write Hadith.

- 'Abdullāh ibn 'Amr tells, "I asked for permission from the Prophet to write what I hear from him. He permitted and I then wrote." 'Abdullāh named his sheets al-Sädiqah. ${ }^{57}$

${ }^{56}$ 'Abū Dāwūd, Al-Sunan, vol. 4 (Beirut: Al-Arqam, 1999), pp. 60-1 Hadith no. 3545; Abdullāh ibn 'Abd al-Raḥmān Al-Dārimī, Sunan al-Dārimì, vol. 1, ed. by Muḥammad Aḥmad Dahmān (Beirut: Dār ị̣yā̄ as-sunnah an-nabawiyyah, 1995), p. 125; Aḥmad Ibn-Hanbal, al-Musnad, vol. 10, ed. by Aḥmad Muḥammad Șākir (Cairo: Dār al-Ma'ārif, 1946), p. 15.

${ }^{57}$ Muḥammad ibn Sa ad, at-Tabaqāt al-Kubrā, vol. 2/2, ed. by Kātib al-Wāqidī (Cairo: Dār al-Tahrīir, 1968), p. 125. 
- Mujāhid said, "I saw sheets with 'Abdullāh ibn 'Amr, I then asked him about that. He answered, "These are al-Sádiqab containing things that I heard from the Prophet directly without intermediary."

These narrations indicate Sahifah al-Sädiqah that belongs to 'Abdullāh ibn 'Amr containing quite a lot of Hadith, because he wrote everything he heard from the Prophet. It is fair if 'Abdullāh ibn 'Amr is known for narrating many Hadith. This is acknowledged by 'Abū Hurayrah r.a himself, a companion with strong memory and narrated many Hadith. This is the blessing of the Prophet's pray that he is given strong memory. All of these increasingly prove that many Hadith were written by 'Abdullāh ibn 'Amr. Al-Bukhāry narrates in his Șabỉh with his sanad that 'Abū Hurayrah says, "There is no companion of the Prophet who narrated Hadith more than me except 'Abdullāh ibn 'Amr, because he writes and I do not write." 58 Abu Hurayrah admitted that the number of Hadith of 'Abdullāh ibn' Amr exceeds the number of his Hadith, because 'Abdullāh bin 'Amr writes while he does not. This narration indicates that the number of Hadith written in the era of the Prophet is huge. Unlike the assumption of some people that sunnah at that time did not get much attention.

This is supported by 'Abdullāh ibn 'Amr who said, "I memorise 1000 Hadith from the Prophet." 59 al-Dhahaby says, "The number of his sanad reaches 700. The number of Hadith that are accommodated in al-Bukhāry and Muslim simultaneously are as much as seven Hadith. Al-Bukhāry narrated by himself as much as eight sanad, and Muslim as much as twenty Hadith." Ahmad narrated the contents of this Sabifah in his musnad, as was counted by 'Ajjāj al-Khathīb in four volumes consecutively. Started from volume 9, page 235 Hadith: 6477 within volumes 10 and 11 included entirely, and ended in volume 12, page 50, Hadith: 7103. Hadith from 'Abdullāh ibn 'Amr are also accommodated in many other Sunnah books. ${ }^{60}$

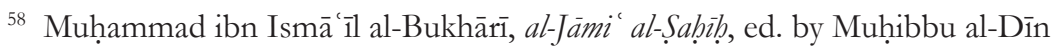
(Cairo: al-Maktabat al-Salafiyyah, 1979), chap. Kitābāt al-'Ilm hadith no. 113.

59 Ṭāhir ibn Șāliḥ ibn Aḥmad al-Jazarī, Tanjīh an-Nažar ilā Ushūl al-Athar, vol. 3 (Aleppo: Maktab al-Mațbū'āt al-Islāmīyah, 2009), p. 349.

${ }^{60}$ Aḥmad Ibn-Hanbal, al-Musnad, vol. 9, ed. by Aḥmad Muḥammad Ṣākir (Cairo: Dār al-Ma'ārif, 1946), p. 235; Aḥmad Ibn-Hanbal, al-Musnad; Aḥmad Ibn-Hanbal, alMusnad, vol. 11, ed. by Aḥmad Muḥammad Ṣākir (Cairo: Dār al-Ma‘ārif, 1946); Aḥmad 


\section{Sabīfah of 'Ali ibn 'Abi Ṭälib}

Although 'Ali ibn 'Abi Ṭālib's narrations are spread out in various sunnah books, his Șabifah (sheets) at a glance only include a small number of Hadith. The fact, however, does not support this. It is proven that these Sahifah contain many themes, as explained by Rif at Fawzy who tahqiq (inspected) and gave annotations (ta'liq). Among the topics of the Hadith is the obligatory of zakat. It is explained in various obligations and the details. This is the same as the description in a note belong to 'Abū Bakar that was written as originated from the Prophet. A stronger opinion states that the description in 'Abū Bakar's note originated from 'Ali ibn 'Abi Ṭālib’s Șahifah ${ }^{61}$ his Șabifah also included various descriptions about diyāt (punishments for physical crimes) and such matters related to crimes against human (jirähät). To strengthen this conclusion, there is a note from the Prophet that was sent to the people of Yemen. That note was then duplicated by the descendant of "Amr ibn Hazm, because his father i.e. 'Amr ibn Hazm was the one who received the note that was sent. This book also explains various duties of Muslim's, sunnah, and diyat.

\section{2. Șahïfah Amr ibn Hazm}

Ibnul Qayyim commented on the note that was sent to 'Amr ibn Hazm, "This book is great and contains many fiqh discussions." 62 Researcher Aḥmad ibn 'Abdurrahmān Al-Ṣuwayyān summarises the topics contained in this book in 21 chapters, as follows: Zakat and nișäb of mining products, Zakat of camels, Zakat of cows, Zakat of goats, Criteria of wealth due for zakat, Zakat of money, Two goods that are mixed with zakat, Zakat for Ablul Bayt (family of the Prophet), No zakat for a muslim slave and his horse, Amount of jizyah, Biggest sins, Prohibition to touch the Qur' an except with purification (ablution), The rule of diyät (fine for murder), Prayer in one cloth, Giving presents, Wheat contract, Prayer times, Abolition remedy / improvement, 'Umrah (minor

Ibn-Hanbal, al-Musnad, vol. 12, ed. by Aḥmad Muḥammad Șākir (Cairo: Dār al-Ma‘̄arif, 1946), p. 50; 'Ajjāj, al-Sunnah Qabla al-Tadwin, p. 350 (footnote).

${ }^{61}$ Rif' at Fawzī, Sahífat 'Al̄i ibn Abī Tălib (Cairo: Maktabat al-Khanjī, 1985), p. 46.

${ }^{62}$ Ibn Qayyim al-Jawziyyah, Zād al-Ma'ād fì Hadyi Khayri al- 'Ibād, vol. 1, ed. by Shu 'ayb al-Arna' ūṭ and 'Abdul Qādir al-Arna' ūṭ (Beirut: Mu'assasat al-Risālah, 1984), p. 199. 
haji), Time of Ṭalāq (divorce), and Time of freeing a slave. ${ }^{63}$

Furthermore, we limit the explanation on some part of the contents of the book, i.e. explanation about diyat and topics that are related to crimes against human (jirähät) to prove that these two topics are also included in the sheets of 'Ali r.a.

'Abū Bakar ibn Hazm narrated from his father, from his grandfather, that the Prophet sent a note to the people of Yemen. The note describes, "that whoever is proven to have killed a mu' min (believer) with no intention (by accident), he has to be qișass (punished), except if the family of the killed person will. Killing a life is obliged to pay diyat." ${ }^{64}$ Al-Baihaqi narrated, when Umar ibn Abdul 'Aziz was the caliph, he sent a Prophet to Medina to search for the Prophet's note about zakäh, including a note belonging to Umar ibn Khattāb. His Prophet found a note that was delivered to 'Amr ibn Hazm about zakāh. On top of that, within the family of 'Umar it was also found his note which also explains similar subject, of which the content is similar to the Prophet's note. Caliph Umar ibn 'Abdul 'Azīz ordered to copy both. ${ }^{65}$ This is a proof that some Hadith that were collected by 'Umar ibn 'Abdul 'Azīz from all directions of Islam territory that were scattered with the companions originated from what have been written from the Prophet. ${ }^{66}$ There are also sheets of Jābir ibn 'Abdullāh al-Anșāry that is very famous among experts of Hadith community. It is said that Mujāhid ibn Jabar narrated from this sheet. ${ }^{67}$ If we know that this noble companion has narrated many useful

${ }^{63}$ See Aḥmad 'Abd al-Raḥmān al-Ṣuwayyān, Șahā' if al-Ṣaḥābah (Riyadh, 1990), p. 114.

${ }^{64}$ Narrated by Ibn Hibbān in the Book of al-Zakāh, Chapter Fard al-Zakāh wa

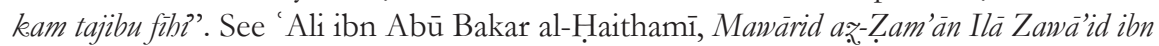
Hibbān, ed. by Muhammad 'Abd ar-Razzāq Hamzah (Beirut: Dār al-Kutub al- 'Ilmiyyah, 1992), pp. 202-3; Muḥammad ibn 'Abd Allāh al-Hākim al-Nīsābūrī, Al-Mustadrak 'Alā Al-Ṣaḩ̌̉hayn, vol. 1 (Beirut: Dār al-Fikr, 1977), pp. 395-7; Aḥmad Ibn-al-Husayn al- Bayhaqīi, al-Sunan al-Kubrā, vol. 4 (India: Dār al-Ma 'rifah and Dā'irat al-Ma'ārif alNizāamiyyah, 1925), pp. 89-90 chapter Kayfa Fard al-Sadaqah; Yūsuf Ibn-'Abdallāh Ibn-'Abd-al-Barr, At-Tambìd, vol. 17 (Ar-Ribāṭ: al-Mamlaka al-Magribīya, 1988), pp. 339-41.

65 Aḥmad Ibn-al-Husayn al- Bayhaqī, al-Sunan al-Kubrā, 4: 91.

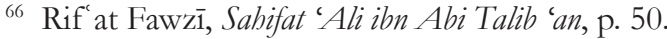

${ }^{67}$ Muhạmmad ibn Sa'ad, at-Tabaqāt al-Kubrā, vol. 5, ed. by Kātib al-Wāqidī (Cairo: Dār al-Taḥrīr, 1968), p. 44. 
knowledges (Hadith) from the Prophet as indicated by al-Dhahabī, ${ }^{68}$ we can be sure that he recorded many Hadith in these sheets.

Al-Dhahabī said, "His musnad reaches 1540 Hadith. The Hadith that are accommodated in both al-Bukhāry and Muslim is an amount of 58 Hadith. Al-Bukhāri narrates by himself an amount of 26 Hadith, while Muslim narrates by himself 126 Hadith." ${ }^{69}$ Amongst the Hadith that were narrated by Muslim in his Șahị that were originated from these sheets are related to hajj guidelines that reach 30 Hadith. $^{70}$ The longest narration was narrated by Jafar ibn Muhammad from his father, from Jābir ibn 'Abdullāh about Haij Wadâ. In the book of Șaḥị̧ Muslim, this Hadith occupies more than 4 pages about the way the Prophet performed hajj entirely.

It is told, Jābir ibn 'Abdullāh wrote Hadith on a plank. Rabî ibn Saad who narrated from Ibnu Abi Shaiba, said, "I saw Jābir at the place Ibnu Thābit while he was writing on a plank." " A number of his students encountered Jābir to write Hadith. 'Abdullāh ibn Muhammad ibn 'Aqīl ibn 'Abi Țālib said, "I used to go with Muhammad ibn 'Ali ibn 'Abū Jafar and Muḥammad al-Hanafiyah to see Jābir ibn 'Abdillāh. We asked him about Sunnah of the Prophet regarding the way he prayed. We wrote and studied from him."그 In addition to 'Abdullāh ibn 'Amr, 'Ali ibn 'Abi Ṭālib, Jābir ibn 'Abdullāh, other companions riḍwānullāh 'alayhym also have notes of Hadith of the Prophet. All of these emphasize that the number of Hadith written in the Prophet's era is huge.

Abū Khaythamah said that ibnu 'Abbās r.a strongly suggested

${ }_{68}$ Muḥammad ibn Aḥmad al-Dhahabī, Tadhkirat al- Huffä̌s, vol. 1 (Hyderabad: Dār Ihyā’ al-Turāth al- 'Arabī, 1956), p. 43.

${ }_{69}$ Muḥammad ibn Aḥmad al-Dhahabī, Siyar A 'lām al-Nubalā', vol. 3, ed. by Shu 'ayb al-Arna' ūṭ (Beirut: Mu'assasat al-Risālah, 1984), p. 197.

${ }^{70}$ Muslim ibn al-Hajjāj al-Nīsābūrī and Muhammad Fu' ad 'Abdul Bāqī, Sahị̣̄ Muslim, vol. 2 (Cairo: Maktabat 'İsā al-Halabī, 1954), pp. 881-93 hadith no. 136-150; Fauzi, Tautsiq al-Sunnah fi al-Qarni Assani al-Hijri., p. 52.

71 Abd Allāh ibn Muhammad al-Kūfī al- 'Absī Ibn Abī Shaybah, al-Muṣannaf fi al-Hadìth wa al-Āthār, vol. 9, ed. by Mukhtār Aḥmad al-Nadawī (Bombay: Dār alSalafiyyah, 1980), p. 49.

72 Aḥmad ibn Muhammad al-Hanafīal-Ṭahāwī, Sharh Ma' āniz al-Athar, vol. 4, ed. by Muḥammad Zuhrī al-Najjār (Beirut: Dār al-Kutub al-'Ilmiyyah, 1978), p. 319;

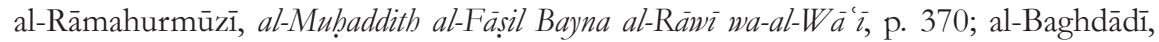
Taquìd al-' $\mathrm{Ilm}$, p. 104. 
the writing of Hadith. He advised, "Tie the knowledge by writing it. Whoever buys knowledge from me with one dirham." "73 Ibnu Saad tells that Ibnu 'Abbās has an amount of notes as much as a camel can carry. ${ }^{74}$ Besides, Samurah ibn Jundub, ${ }^{75}$ also has notes that is well known in the community of Hadith experts. It is possible that these Samurah sheets are the letters directed to his children. These sheets contain various Hadith, as mentioned and praised by Ibnu Sīrīn. ${ }^{76}$ Ibnu Hajar has the same opinion, as shown in al-Tabdhib, when explaining Sulaiman ibn Samurah's profile. "He narrated from his father a big number of copies", wrote Ibnu Hajar. ${ }^{77}$ This note belongs to Samurah containing a big number of Hadith of the Prophet. 'Abūl Wasim at-Tabarany narrated in al-Mu'jam al-Kabir a large number of Hadith, up to 95 Hadith without repetition. ${ }^{78}$ All are narrated from one path, i.e. Jafar ibn Saad ibn Samurah, from Khubaib ibn Sulaiman ibn Samurah, from his father Samurah ibn Jundab. Part of these narrations are included by al-Bukhāry in his Sabīh book. These sheets maybe the letter he sent to his children, maybe not. ${ }^{79}$ All of these scripts confirm that the number of Hadith that were written in the era of the Prophet is significant.

${ }^{73}$ 'Abū Khaithamah Zuhair ibn Harb al-Nasā'̄', Kitab al-' $\mathrm{Ilm}$, ed. by Muhammad Nāṣiruddī̄n al-Albānī (Damascus: al-Maṭba at al- 'Umūmiyyah), p. 144.

${ }^{74}$ Muḥammad ibn Sa'ad, at-Tabaqät al-Kubrā, 5: 216. biography of Kurayb ibn Abī Muslim.

${ }^{75}$ Samurah ibn Jundab ibn Hilāl ibn jurayj ibn Murrah al-Fazārī is one of the elite companions. He narrates many Hadith from the Prophet, lived and died in Basrah, very hard against the Khawārij until he killed some of them hence they reproached him, see; Alī ibn Muhammad al-Jazarī, Usud al-Ghābah fì Ma' rifah al-Sahäbah, vol. 2, ed. by Muḥammad Ibrāhīm al-Bannā (Cairo: Ṭab at al-Sha 'b, 1970), p. 354; Muhyi al-dīn ibn Sharaf al-Nawawī, Tahdhìb al-Asmā’ wa al-Lughät, vol. 1 (Cairo: Idārat at-Tibā' at alMun̄iriyyah, 1977), p. 235; Muḥammad ibn Aḥmad al-Dhahabī, Siyar A 'lām al-Nubalā', 3: 183; Aḥmad ibn 'Alī Ibn Ḥajar al-Asqalānī̄, al-'Isābah fì Tamyìz al-Sahāābah, vol. 2 (Beirut: Maktabat al-Muthannā, 1910), p. 77.

${ }^{76}$ Aḥmad Ibn Ali Ibn Ḥajar al-Asqalāniī, Tahdhïb al-Tahdhỉb, vol. 4 (Hyderabad: Dār al-Ma àrif al-Nizāāmiyyah, 1907), p. 236; al-Asqalāniī, al-'Isābah fì Tamyì̃ al-Sahāābah, 2: 77 .

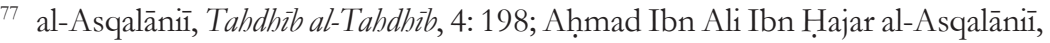
Tahdhīb al-Tahdhīb, vol. 3 (Hyderabad: Dār al-Ma àrif al-Nizāmiyyah, 1907), p. 135.

78 Sulaimān ibn Aḥmad al-Ṭabrānī, al-Mu'jam al-Kabìr, vol. 7, ed. by Hamdī al-Salafī (Baghdad: Wizārat al-Awqāf, 1977), pp. 295-325.

${ }^{79}$ Rif'at Fawzì 'Abd al-Muțtalib, Tawthì al-Sunnah (Cairo: Maktabat al-Khānjī, 1981), p. 52. 


\section{H. The Companions Do Not Memorise Hadith}

Harun's argument that companions do not memorise Hadith is strange. In a simple logic, if they were neither written nor memorised. How can the sunnah be conveyed from the companions to the next generations? There are a lot of evidences that the companions memorised the Hadith. In this regard, we cited some acknowledgements of companions and tabi $i n$ who emphasized that before they were written, the Hadith were memorised first. In this case, their explanations are positioned to answer Harun's assertion. Abū Naḍrah, a tabi în, tells his conversation with 'Abū Said. He requested Abū Said to write Hadith of the Prophet because he was not able to memorise them. Abū Said rejected. His reason was that memorisation is a main tool to protect the sunnah of the Prophet and the most used method by the companions. Abū Naḍrah says, "I said to Abi Said, "please write the Hadith, because we cannot memorise." Abu Said replied, "We do not write them for you and we do not make it a mushaf. He tells us and we memorise them." His message is, "Memorise from us like we memorise from the Prophet." 80 Similar to that, 'Abū Musa al-Ash ary instructed, "Memorise from us like we memorise before." ${ }^{81}$ There is a lot of information, especially about famous companions that have memorised Hadith and narration, such as 'Abū Hurayrah r.a., Sa îd ibn 'Abil Hasan says, "There is no companion of the Prophet that narrates more Hadith from the Prophet except 'Abū Hurayrah." 82

This life pattern of companions is followed by tabi 1 in generation that came after them. 'Abū Sufyān stated his viewpoint not to write and rely on memorisation by heart, he says, "I do not write the Hadith from 'Abū Hurayrah, but we memorise them." ${ }^{83}$ Therefore, the tabi ${ }^{1}$ n were trained to memorise Hadith and did not write them except in some situations. Khalid al-Hadha' (141 AH) says, "I do not write something except a long Hadith. When I have memorised it, I then erase it." ${ }^{84}$

80 al-Baghdādī, Taquìd al- 'Ilm, p. 36; al-Rāmahurmūzīi, al-Muḥaddith al-Fāṣil Bayna al-Rāwì wa-al-Wāì , p. 379.

81 Aḥmad ibn 'Alī al-Khațīb al-Baghdādī, al-Kifāyah fì 'Ilm al-Riwaàyah, p. 40.

82 Ibid., p. 41.

83 Ibid., p. 47.

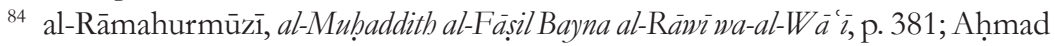
ibn 'Alī al-Khațīb al-Baghdādī, al-Kifāyah fì 'Ilm al-Riwāyah, p. 59. 
Similar description was also narrated by 'Așim ibn Damrah. Al-Dhahaby summarizes scientific characteristics of the first generation. "Verily the knowledge of the companions and tabi ${ }^{\mathrm{i}} n$ is on their heart (memorised by heart-translator). That is the warehouse of their knowledge", says alDhahaby. ${ }^{85}$ Abū TTălib al-Makky (381 AH) mentions, the first generation of tabi ${ }^{1} n$ does not like taking note of Hadith. They say, "Memorise, like you memorise." 86 This is their attitude in keeping the sunnah. Like illustrated by Ibnu Hajar, "A group of companions and tabi 1 n do not like writing the Hadith and prefer people to narrate from them by memorising, just like the way they did. However, when the attention is getting less, and the scholars worry that the Hadith are vanished, they then write them." ${ }^{87}$

Groups of people who watch Arab nation in jäbiliyyah (darkness) era and early Islam know for sure that they have strong memory. They used to go to "sūq al-adab" (literature market) and recite poems in form of qasidah (bunch of poem couplet). By hearing once, they memorise immediately. With this condition, it is natural that the Prophet explains the characters of this ummah through his saying, "Their holy book is in their heart, they recite it fluently." ${ }^{\text {" }}$ Meaning, "As if those sheets of the book are in their heart." ${ }^{89}$ Qatādah says, "When my ears hear something, I memorise it immediately." Ibnu Shihāb az-Zuhry says, "When passing through Baqi' area, I am forced to plug my ears. I fear of hearing impolite words. By God, I never forget what I hear." ${ }^{\prime 0}$ In another place az-Zuhry says, "I do not repeat even one Hadith. I have never doubt any Hadith except for one. I then asked my companion, and he mentioned like what I have memorised." ${ }^{91}$

The number of Hadith that were memorised by az-Zuhry, as mentioned by 'Abū Dāwūd, is up to 2200 Hadith, half of it in the

${ }^{85}$ Cited from al- 'Ish, 'Introduction', p. 6.

${ }^{86}$ 'Abū Ṭālib Muḥammad ibn 'Ațiyyah al-Hārithī al-Makkī, Qūt al-Qulūb, vol. 1 (Cairo: Mațba 'at al-Anwār Al-Muhammadiyyah, 1984), p. 351.

87 al-Asqalānī, Fath al-Bārì, 1: 208.

${ }^{88}$ Abū Na'̄̄m Ahmad ibn 'Abd Allāh ibn Ahmad Aṣbahānī, Dalāìl al-Nubümwah (Baghdad: Maktabat al-Nahḍah, 1984), pp. 30-1.

89 'Abd al-Muhdīi ibn 'Abd al-Qadīr ibn 'Abd al-Hādī, al-Sunnah al-Nabawiyyah: Makānatuhā, 'Awāmil Baqā̀ ìnā, wa Tadwinnuhà (Cairo: Dār al-I'tiṣām, 1989), p. 73.

90 al-Barr, Jāmì Bayān al- 'Ilm wa Fadlih, 1: 83.

91 Muḥammad ibn Aḥmad al-Dhahabī, Tadhkirat al- Huffä̌s, 1: 111. 
Daud Rasyid et al.

form of musnad."92 This superiority is not only possessed by az-Zuhry. Sufyān once said about his memorisation, "My memory has never stored something then betrayed me." ${ }^{\prime 3}$ These various descriptions explain that memorising was the main method in keeping the sunnah, whether in period of companions or tabi in. Another way was writing, which was also started in the era of the Prophet.

\section{Cautious Behaviour of the Companions}

The companions are entirely conscious that sunnah is nonseparated part of Allāh's religion. Because, as we have mentioned, the Qur' an commands to obey the instructions of the Prophet and to stay away from his prohibitions, to follow his example, and to shadow his sunnah. Even, the Prophet threatens people who leave and ignore the sunnah, excusing that the Qur' an is sufficient. Since the beginning, the Prophet has revealed, the existence of certain groups with the intention of ripping out Islam by separating Kitābullāh from Sunnah. They have an assumption that they must only follow the Qur' an by ignoring the sunnah. The Prophet knew this trend from the beginning, hence he felt necessary to remind his ummah so that they are not trapped into such misleading belief about their religion. The Prophet said, "There will be a time when one of you is sitting on his bed, then submitted to him my commands and prohibitions, he then says, 'I do not know, we follow those contained in the book of Allāh only."'94

Those companions have experienced the important role of sunnah since the revelation of verses of the Qur' an which have a characteristic of mujmal (common, requires explanation) such as saläh, zakäh, fast, and bajj. All of those obligatory cannot be done without the explanations from sunnah. They cannot understand except by going back to the Prophet as an implementation of Allāh's saying, meaning: And We send down to you the Qur'an, so that you explain to mankind what have been revealed to them (Qur'an, 16: 44).

Furthermore, some verses are general and absolute, and the

${ }_{92}$ Ibid., 1: 109.

93 Ibid., 1: 204.

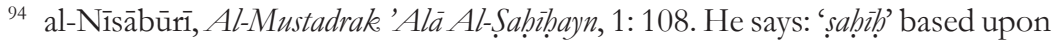
the criteria of al-Bukhārī Muslim, and agreed upon al-Dhahabī 
companions did not know their practical implementations. They referred to sunnah about the general verses exceptions or the limitations of the absolute verses. Besides, like the Qur'an, sunnah also apply rules independently, because they are not in the Qur'an. Therefore, the companions needed the sunnah very much. This need necessitated them to narrate, to keep, to memorise, and to pass down the Hadith to the generations that were born later. They seriously guarded the sunnah, since they received them from the Prophet and later conveying them to the next generation in a sabih way and correct methods, without distortion and manipulation by adding to or subtracting from it. ${ }^{95}$

\section{J. Concluding Remarks}

The evidences as discussed in this article clearly indicated, that the Hadith has been written since the era when the Prophet was still alive. Numerous studies carried out in the past had indicated that it is a historical fact. Furthermore, this assertion is not questioned by eminent orientalists and the written Hadith were later preserved in the form of Sabifah (sheets) which contained Hadith of the Prophet that were narrated by a number of companions. The objections of some companions in receiving Hadith from other companions was not because they did not trust the truthfulness of the companions, but due to their careful attitude in receiving information from someone that attributes the saying to the Prophet, because the saying of the Prophet is not the same as the saying of other human. Furthermore, their objection did not negate the fact that Hadith was not written in the era of the Prophet. The claim that Hadith were written two centuries after the death of the Prophet is a claim without sound foundations, but rather based on unfounded suspicions, bias, and lack of understanding in reading Islamic texts. Hadith that are delivered by the Prophet to the companions, forwarded to the next generations, have gone through a process that is justified and there is no chance for prejudice and sbububät (hesitance) to weaken the strength of Hadith as hujjah (guidance) in Sharia Law.

${ }^{95}$ Rif'at Fawzy, Tawthiq al-Sunnah, op. cit., p. 26 
Daud Rasyid et al.

\section{BIBLIOGRAPHY}

Abdullah, Ismail, 'Early Blogging for the Year is an Authentic Study and Curriculum', Ma'alim Al-Quran Wa Al-Sunnah, vol. 2, no. 2, 2006, http://ddms.usim.edu.my:80/jspui/handle/123456789/15703, accessed 27 Nov 2020.

al-Bukhārī, Muḥammad ibn Ismā'îl, al-Jāmi al-Sahị̂̉, ed. by Muhibbu al-Dīn, Cairo: al-Maktabat al-Salafiyyah, 1979.

Al-Dārimī, Abdullāh ibn 'Abd al-Raḥmān, Sunan al-Dārimì, vol. 1, ed. by Muḥammad Aḥmad Dahmān, Beirut: Dār iḥyā' as-sunnah annabawiyyah, 1995.

Ahmad, Mahmud Idan, 'Tadwīn al-Hadīth 'ala 'ahd al-Naby wa Șahābatihi', Journal of Tikerit University for the Humanities, vol. 13, no. 2, 2006, pp. 7-45.

Aṣbahānī, Abū Na'īm Aḥmad ibn 'Abd Allāh ibn Aḥmad, Dalāìl alNubuiwwah, Baghdad: Maktabat al-Nahḍah, 1984.

----, Hilyat al-Awliy $\vec{a}$, vol. 1, Cairo: Maṭba at al-Sa'ādah, 1974.

al-Asqalānī, Aḥmad ibn 'Alī Ibn Hajar, Fath al-Bārì, vol. 1, ed. by Muhib al-dīn al-Khațīb, Cairo: Maktabat al-Salafiyyah, 1986.

al-Asqalānī̄, Aḥmad Ibn Ali Ibn Hajar, Tahdhīb al-Tahdhìb, vol. 3, Hyderabad: Dār al-Ma'ārif al-Nizāamiyyah, 1907.

----, Tahdhìb al-Tahdhìb, vol. 4, Hyderabad: Dār al-Ma ārif al-Niẓāmiyyah, 1907.

----, Tahdhīb al-Tahdhìb, vol. 7, Hyderabad: Dār al-Ma ārif al-Nizāmiyyah, 1907.

----, Tahdhìb al-Tahdhìb, vol. 10, Hyderabad: Dār al-Ma ārif al-Niẓāmiyyah, 1907.

----, Tahdhìb al-Tahdhìb, vol. 11, Hyderabad: Dār al-Ma ārif al-Niẓāmiyyah, 1907.

al-Asqalāniī, Aḥmad ibn 'Alī Ibn Hajar, al-'Ișäbah fì Tamyìz al-Sahābah, vol. 2, Beirut: Maktabat al-Muthannā, 1910.

Baba, Fathi Daday, 'Kitābat al-Hadīth fì Zaman al-Naby bayna al-Nafyi wa al-Ithbāt', Al-Haqiqah Journal, vol. 15, no. 37, 2016, pp. 149-71. 
al-Baghdādī, Aḥmad ibn 'Alī al-Khațīb, Taqyìd al- 'Tlm, ed. by Yusuf al'Ish, Damascus: Dār Ihyā al-Sunnah al-Nabawiyyah, 1974. ----, al-Kifāyah fì 'Ilm al-Riwaàyah, Beirut: Dār al-Kutub al- 'Ilmiyyah, 1974. al-Barr, Yūsuf ibn 'Abd, Jämī' Bayān al-'Tlm wa Fadlih, vol. 1, ed. by 'Abd al-Rahmmān Muhammad 'Uthmān, Medina al-Munawwarah: al-Maktabat al-Salafiyyah, 1968.

----, At-Tambìd, vol. 17, Ar-Ribāṭ: al-Mamlaka al-Magribīya, 1988.

al-Bayhaqīi, Aḥmad Ibn-al-Husayn, al-Sunan al-Kubrā, vol. 4, India: Dār al-Ma rifah and Dā’irat al-Ma ārif al-Niz̄āmiyyah, 1925.

Dāwūd, 'Abū, Al-Sunan, vol. 4, Beirut: Al-Arqam, 1999.

al-Dhahabī, Muḥammad ibn Aḥmad, Tadbkirat al- Huffäă, vol. 1, Hyderabad: Dār Ihyā' al-Turāth al- 'Arabī, 1956.

----, Mì̃ān al-I tidāl fì Naqd al-Rijäl, vol. 2, ed. by Ali Muhammad al-Bajāwī, Cairo: Maktabat 'Îsā al-Halabī, 1962.

----, Siyar A 'làm al-Nubalà', vol. 3, ed. by Shu'ayb al-Arna' ūț, Beirut: Mu'assasat al-Risālah, 1984.

Fawzī, Rif'at, Tawthìq al-Sunnah, Cairo: Maktabat al-Khānjīi, 1981.

----, 'Introduction', in Sahifat Hammām ibn Munabbih, Cairo: Maktabah al-Khanjīi, 1985.

----, Sahîfat 'Alī ibn Abì Ṭălib, Cairo: Maktabat al-Khanjīi, 1985.

Goldziher, Ignaz, Muslim Studies, vol. 2, Albany: State University of New York Press., 1971.

al-Hādī, 'Abd al-Muhdī ibn 'Abd al-Qadīr ibn 'Abd, al-Sunnah alNabawiyyah: Makānatuhā, 'Awāmil Baqāìhā, wa Tadwinubā, Cairo: Dār al-I'tișām, 1989.

al-Haithamī, 'Ali ibn Abū Bakar, Mawārid až-Zam'ān Ilā Zawāid ibn Hibbān, ed. by Muḥammad 'Abd ar-Razzāq Hamzah, Beirut: Dār al-Kutub al-'Ilmiyyah, 1992.

Huseen, Mohamad Ali and Basim Kanaan Saleh, "al-Kuttāb fì al-'Ahd al-Nabawy (In the book During Prophet Muhammad Era)", Journal of Research Diyala Humanity, no. 47, 2010, pp. 563-87.

Ibn-Ḥanbal, Aḥmad, al-Musnad, vol. 9, ed. by Aḥmad Muḥammad Ṣākir, Cairo: Dār al-Ma‘̄ārif, 1946. 
Daud Rasyid et al.

----, al-Musnad, vol. 10, ed. by Aḥmad Muḥammad Șākir, Cairo: Dār alMa ārif, 1946.

----, al-Musnad, vol. 11, ed. by Aḥmad Muḥammad Ṣākir, Cairo: Dār alMa‘ārif, 1946.

----, al-Musnad, vol. 12, ed. by Aḥmad Muḥammad Șākir, Cairo: Dār alMa'ārif, 1946.

ibn Sa'ad, Muhammad, at-Tabaqāt al-Kubrā, vol. 2/2, ed. by Kātib alWāqìī, Cairo: Dār al-Tahrīir, 1968.

----, at-Tabaqāt al-Kubrā, vol. 5, ed. by Kātib al-Wāqidī, Cairo: Dār alTahrīir, 1968.

al-Jawziyyah, Ibn Qayyim, Zād al-Ma'àd fì Hadyi Khayri al- 'Ibād, vol. 1, ed. by Shu 'ayb al-Arna' ūt and 'Abdul Qādir al-Arna' ūṭ, Beirut: Mu’assasat al-Risālah, 1984.

al-Jazarī, Ṭāhir ibn Ṣālih ibn Aḥmad, Tawjīh an-Naẓar ilā Ushūl al-Athar, Aleppo: Maktab al-Maṭbū'āt al-Islāmīyah, 2009.

----, Tawjīh an-Nazar ilā Ushül al-Athar, vol. 3, Aleppo: Maktab al-Maṭū'àt al-Islāmīyah, 2009.

al-Jazarī, 'Alīibn Muhammad, Usud al-Ghäbah fì Ma' rifah al-Ṣạ̄äbah, vol. 3, ed. by Muḥammad Ibrāhīm al-Bannā, Cairo: Ṭab 'at al-Sha 'b, 1970.

----, Usud al-Ghābah fi Ma'rifah al-Șahābah, vol. 2, ed. by Muhammad Ibrāhīm al-Bannā, Cairo: Tab' at al-Sha 'b, 1970.

al-Karim, Ahmad Ma'bad Abd, Kitābat al-Hadìth fi' 'ahd al-Naby wa Sahābatibi, Medina: Majma' al-Malik Fahad Li Thiba'at al-Mushaf, 2020, https://www.islamspirit.com/islamspirit_ilmolma_002_00023.php, accessed 27 Nov 2020.

Mahmud, Muhammad Ied, "Kitābat al-Hadīth fī "Așr al-Ṣahābah", Majallah al-Jami'ah li al-Dirasat al-Islamiyah (Journal of Islamic Studies ), vol. 28, no. 1, 2020 [https://doi.org/10.33976/iugjis.v28i1.4887].

al-Makkī, 'Abū Ṭālib Muḥammad ibn 'Ațiyyah al-Hārithī, Qūt al-Qulūb, vol. 1, Cairo: Maṭba' at al-Anwār Al-Muhammadiyyah, 1984.

al-Mu'allamī, 'Abd al-raḥmān ibn Yaḥyā, Al-Anwār al-Kāshifah Limā Warada fi Kitāb Aḍw' 'ala al-Sunnah min al-Zalal wa al-Tadlil wa alMujärafah, Cairo: al-Mața' at al-Salafiyyah, 1953.

al-Nasā'̄', 'Abū Khaithamah Zuhair ibn Harb, Kitab al-'Ilm, ed. by 
Muhammad Nāṣiruddī̄n al-Albānī, Damascus: al-Maṭba'at al'Umūmiyyah.

Nasution, Harun, Islam Ditinjau Dari Berbagai Aspeknya, vol. 1, Jakarta: UI press, 1985.

al-Nawawī, Muhyyi al-dīn ibn Sharaf, al-Taqrīb, vol. 1, Cairo: Dār al-Kutub al-Hadith, 1965.

----, Muhyi al-dīn ibn Sharaf, Tahdhïb al-Asmä wa al-Lughät, vol. 1, Cairo: Idārat at-Tibā' at al-Munīriyyah, 1977.

al-Nīsābūrī, Muhammad ibn 'Abd Allāh al-Hākim, Al-Mustadrak 'Alā Al-Ṣahihayn, vol. 1, Beirut: Dār al-Fikr, 1977.

al-Nīsābūrī, Muslim ibn al-Hajjāj and Muhammad Fu' ad 'Abdul Bāqī, Sahīh Muslim, Cairo: Maktabat 'İsā al-Halabīi, 1954.

Qutaybah, Abd Allāh ibn Muslim al-Dīnawarī Ibn, Ta’wil Mukhtalaf al-HìHadith, ed. by 'Abd al-Qadīr 'Ațā, Cairo: Dār al-Kutub alIslāmiyyah, 1981.

al-Rāmahurmūzī, Al-Hasan ibn 'Abd al-Raḥmān, al-Muhaddith al-Fāsil Bayna al-Rāwñ wa-al-Wāi $i$, ed. by M. 'Ajjāj al-Khatīb, Damascus: Dār al-Fikr, 1971.

Rukabah, Hassan, 'Tațawwur Kitābah al-Hadith al-Nabawī al-Sharīf ilā Așr al-Tadwīn', Al-Míyar Journal, vol. 16, no. 32, 2020, pp. 137-67. al-Sakhāwī, Muhammad ibn 'Abd ar-Rahmān, Fatḥ al-Mughith Sharh Alfiyyat al-Hadith, vol. 3, Saudi Arabia: Wizarat al-Shu'un al-Islamiyah wa al-Awqaf wa al-Da'wah wa al-Irshad, 2003.

al-Ṣalāh, 'Uthmān ibn 'Abd al-Rahmān al-Shaharzūrī Ibn, al-Muqaddimah fì 'Ulüm al-Hadith, ed. by Nūruddin 'Itr, Damascus: Dār al-Fikr, 1985. al-Ṣawwaf, Khaulah Hamdun, "Abdullāh Ibn 'Amr Ibn al-'Ash, Al-Ṣahāāī al-Muhaddith", Journal of Tikrit University for the Humanities, vol. 14, no. 1, 2007, pp. 71-92.

Shahbah, Muhammad 'Abū, Difā'c 'an as-Sunnah, Cairo: Mağma' al-buhūt al-islāmiyyah, 1985.

Shaybah, Abd Allāh ibn Muḥammad al-Kūfì al- 'Absī Ibn Abī, al-Muṣannaf fì al-Hadith wa al-Āthār, vol. 9, ed. by Mukhtār Ahmmad al-Nadawī, Bombay: Dār al-Salafiyyah, 1980. 
Daud Rasyid et al.

Sibāic̄, Muștafá, As-Sunnah wa Makānatubā fì at-Tashrī al-Islāmiy, Cairo: al-Dār al-Qawmìyah lil-Ṭibā‘ah wa-al-Nahsr, 1966.

al-Ṣuwayyān, Aḥmad 'Abd al-Raḥmān, Sahǟ' if al-Sahābah, Riyadh, 1990. al-Suyūṭị, Jalāl al-dīn 'Abd al-Raḥmān, Tadrìb al-Rāwì fì Sharḅ Taqrìb alNawawì, vol. 2, ed. by 'Abd al-Wahhāb 'Abd al-Lațîf, Cairo: Dār al-Kutub al-Hadith, 1965.

al-Ṭabrānī, Sulaimān ibn A ḥmad, al-Mu jam al-Kabìr, vol. 7, ed. by Hamdī al-Salafì, Baghdad: Wizārat al-Awqāf, 1977.

al-Ṭahāwīi, Aḥmad ibn Muḥammad al-Hanafí, Sharh Ma'ànī̄ al-Athar, vol. 4, ed. by Muḥammad Zuhrī al-Najjār, Beirut: Dār al-Kutub al-'Ilmiyyah, 1978.

al-'A 'ẓamī, Muḥammad Musțafā, Dirāsāt fì Hadith al-Nabawì wa Tärìkh Tadwinnih, vol. 1, Beirut: Manshūrāt al-Maktab al-Islāmī, 1992.

'Ajjāj, Muhammad, al-Sunnah Qabla al-Tadwin, Cairo: Maktabat Wahbah, 1963.

al- 'Ish, Yusuf, "Introduction", in Taqyìd al- 'Ilm, Damascus: Dār Ihyā alSunnah al-Nabawiyyah, 1974. 